\title{
Perhedaan Skor Sepsis Modifiikasi Tollner dan Kadar Procalsitonin Serum Sebelum dengan Setelah Pemberian Antibiotik Empiris pada Sepsis Neonatorum
}

\author{
Amelia Harsanti, Nanan Sekarwana, Kusnandi Rusmil \\ Departemen Ilmu Kesehatan Anak Fakultas Kedokteran Universitas Padjadjaran/Rumah Sakit Dr. Hasan \\ Sadikin, Bandung
}

\begin{abstract}
Latar belakang. Di negara maju maupun berkembang, insiden sepsis neonatorum masih tinggi. Penggunaan antibiotik empiris, pada sepsis neonatorum, perlu pemantauan ketat untuk mencegah toksisitas dan resistensi. Tujuan. Menentukan perbedaan skor sepsis modifikasi Tollner dan kadar procalcitonin (PCT) serum sebelum dengan setelah pemberian antibiotik empiris serta hubungan perubahan keduanya pasca pemberian antibiotik empiris.

Metode. Penelitian observasional analitik, rancangan one group pre-test and post-test, dilaksanakan Juli-Oktober 2013 di Unit Gawat Darurat dan Rawat Inap Divisi Neonatologi Rumah Sakit Dr. Hasan Sadikin, Bandung. Subjek penelitian terdiri atas 32 neonatus dan 2 dikeluarkan karena meninggal $<48$ jam. Pada seluruh subjek dilakukan penilaian skor sepsis (nilai > 10 masuk ke dalam penelitian) dan pemeriksaan kadar PCT serum sebelum dengan setelah mendapat antibiotik ampisilin dan gentamisin selama 48 jam. Perbedaan skor sepsis modifikasi Tollner dan kadar PCT sebelum dengan setelah pemberian antibiotik empiris dianalisis menggunakan Uji Wilcoxon. Korelasi perubahan skor sepsis dan kadar PCT diuji dengan Uji Rank Spearman. Faktor yang berhubungan dengan skor sepsis dan kadar PCT jenis kelamin, usia $\leq 48$ jam, berat lahir rendah, dan kultur darah negatif dianalisis dengan Uji Mann-Whitney.

Hasil. Skor sepsis dan kadar PCT serum awal (median (rentang)) berturut-turut 11,5 (10,5-16,5) dan 12,6 $(0,30-100) \mathrm{ng} / \mathrm{mL}$. Pasca pemberian antibiotik berturut-turut $5,5(0,5-13,5)$ dan $2,65(0,16-37,25) \mathrm{ng} /$ mL. Skor sepsis dan kadar PCT berbeda bermakna sebelum dengan setelah pemberian antibiotik empiris. Terdapat korelasi positif bermakna perubahan nilai skor sepsis modifikasi Tollner dengan perubahan kadar PCT serum pasca pemberian antibiotik empiris selama 48 jam.

Kesimpulan. Skor sepsis modifikasi Tollner dan kadar PCT serum berhubungan dengan pemberian antibiotik empiris pada sepsis neonatorum. Kenaikan perubahan skor sepsis modifikasi Tollner diikuti oleh kenaikan perubahan kadar PCT serum. Sari Pediatri 2014;16(3):178-82
\end{abstract}

Kata kunci: antibiotik empiris, procalsitonin, sepsis neonatorum, skor sepsis modifikasi Tollner

\footnotetext{
Alamat korespondensi:

Dr. Amelia Harsanti, SpA. Kusnandi Rusmil.Departemen Ilmu Kesehatan Anak Fakultas Kedokteran Universitas Padjadjaran/Rumah Sakit Dr. Hasan Sadikin. Jl. Pasteur No. 38 Bandung 40163, Indonesia. Telp. (022) 2035957. E-mail: aharsanti@yahoo.com
}

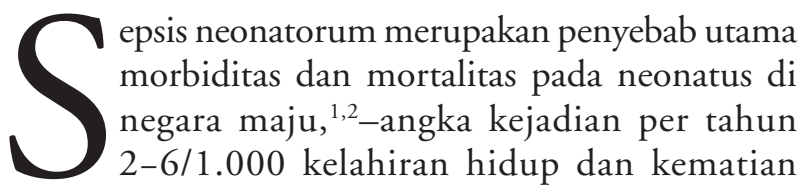


$10,3 \%{ }^{3,4}$ Sementara itu, di negara berkembang, angka kejadian 1,8-18/1.000 kelahiran hidup dengan angka kematian 12\%-68\%. ${ }^{3,4}$ Di beberapa rumah sakit di Indonesia, insiden sepsis neonatorum $1,5 \%-3,72 \%$ dengan angka kematian 37,09\%-80\%. Setiap kasus sepsis neonatorum diberikan antibiotik empiris selama 48-72 jam sehingga terbukti tidak sesuai dengan kuman penyebab sepsis. ${ }^{6}$ Pemantauan respons antibiotik empiris dilakukan berdasarkan gejala klinis dan laboratorium. ${ }^{6,7}$ Sistem skoring sepsis yang dikemukakan oleh Tollner terdiri atas penilaian klinis yang dipadukan dengan hasil laboratorium, digunakan untuk menegakkan diagnosis sepsis neonatorum apabila skor $>10 .^{8}$ Skor sepsis modifikasi Tollner diharapkan menurun apabila antibiotik empiris yang digunakan sesuai.

Pemeriksaan procalsitonin (PCT) serum secara serial dapat digunakan untuk pemantauan respons terapi antibiotik pada infeksi neonatus. ${ }^{9,10}$ Pada 24 jam pasca pemberian antibiotik, penurunan kadar PCT $\geq 30 \%$ menunjukkan bahwa antibiotik yang digunakan sudah sesuai dan infeksi terkendali. ${ }^{10-12}$ Tujuan penelitian ini adalah menentukan perbedaan skor sepsis modifikasi Tollner dan kadar PCT serum sebelum dengan setelah mendapat antibiotik empiris, serta korelasi perubahan skor sepsis dengan perubahan kadar PCT serum pasca pemberian antibiotik empiris pada sepsis neonatorum.

\section{Metode}

Penelitian observasional analitik dengan rancangan one group pre-test and post-test terhadap neonatus dengan diagnosis sepsis neonatorum. Penelitian dilaksanakan pada bulan Juli-Oktober 2013 di Unit Gawat Darurat dan Rawat Inap Divisi Neonatologi Rumah Sakit Dr. Hasan Sadikin, Bandung. Lembar persetujuan (informed consent) ditandatangani oleh orangtua setelah mendapatkan penjelasan serta menyetujui bayinya ikut dalam penelitian. Kriteria inklusi adalah neonatus usia 0 sampai dengan 28 hari yang memenuhi skor $>10$ pada penilaian skor sepsis modifikasi Tollner serta belum pernah mendapat antibiotik sebelumnya. Kriteria eksklusi adalah bayi dengan kelainan bawaan mayor, hemodinamik tidak stabil/kondisi kritis (syok, gagal nafas), kurang bulan (prematuritas), bayi dengan kecurigaan enterokolitis nekrotikans, dan bayi dengan kecurigaan perdarahan intraserebri. Subjek penelitian yang meninggal $<48$ jam tidak diikutsertakan dalam penelitian.

Pemilihan subjek dilakukan secara berurutan (consecutive). Seluruh subjek dilakukan penilaian skor sepsis modifikasi Tollner serta pemeriksaan kadar PCT serum menggunakan metode Elecsys BRAHMS PCT dengan teknik electrochemiluminescence immunoassay (ECLIA) masing-masing sebelum dengan setelah mendapat antibiotik ampisilin dan gentamisin selama 48 jam. Perbedaan skor sepsis modifikasi Tollner dan kadar PCT serum dianalisis menggunakan $\mathrm{Uji}_{\mathrm{j}}$ Wilcoxon. Korelasi perbedaan skor sepsis dengan perbedaan kadar PCT serum pasca pemberian antibiotik empiris ditentukan melalui uji korelasi Rank Spearman. Faktor yang berhubungan dengan skor sepsis dan kadar PCT serum-jenis kelamin, usia $\leq 48$ jam, berat lahir rendah, kultur darah negatifdianalisis dengan Uji Mann-Whitney. Perhitungan statistik menggunakan program SPSS versi 17.0. Penelitian telah mendapatkan persetujuan Komite Etik Penelitian Kesehatan Fakultas Kedokteran Universitas Padjadjaran/RS Dr. Hasan Sadikin, Bandung.

\section{Hasil}

Subjek penelitian terdiri atas 32 neonatus, 2 dikeluarkan dari penelitian karena meninggal $<48$ jam. Karakteristik umum subjek penelitian meliputi jenis kelamin, usia, dan cara persalinan. Karakterisitik umum subjek penelitian tertera pada Tabel 1. Sebaran usia subjek tidak normal. Perbedaan skor sepsis modifikasi Tollner dan kadar PCT serum berdasarkan jenis kelamin, usia, berat badan lahir, dan hasil kultur darah negatif tertera pada Tabel 2. Tabel 2 juga menunjukkan variabel yang berhubungan dengan skor sepsis modifikasi Tollner dan kadar PCT serum tidak berbeda bermakna.

Tabel 1. Karakteristik subjek

\begin{tabular}{lc}
\hline Karakteristik & $\mathrm{N}$ \\
\hline Jenis kelamin & \\
$\quad$ Laki-laki & 17 \\
$\quad$ Perempuan & 13 \\
Usia (jam) & \\
$\quad$ Median & 66,5 \\
$\quad$ Rentang & $3-644$ \\
Cara persalinan & \\
$\quad$ Spontan & 24 \\
$\quad$ Sectio Caesaria & 6 \\
\hline
\end{tabular}


Amelia Harsanti dkk: Perbedaan skor sepsis modifikasi Tollner dan PCT serum sebelum dengan setelah pemberian antibiotik

Tabel 2 Perbedaan skor sepsis modifikasi Tollner dan kadar PCT serum

\begin{tabular}{|c|c|c|c|c|c|c|c|}
\hline \multirow{2}{*}{ Karakteristik } & \multicolumn{4}{|c|}{ Skor sepsis modifikasi Tollner } & \multicolumn{3}{|c|}{ Kadar PCT serum } \\
\hline & $\mathrm{N}(30)$ & Median & Rentang & $p$ & Median & Rentang & $\mathrm{p}$ \\
\hline Jenis kelamin & & & & $0,59^{*}$ & & & $0,66^{*}$ \\
\hline Laki-laki & 17 & 11,5 & $10,5-16,5$ & & 2,84 & $0,03-58,51$ & \\
\hline Perempuan & 13 & 11,5 & $10,5-13,5$ & & 1,58 & $0,07-100,0$ & \\
\hline Usia (jam) & & & & $0,17^{*}$ & & & $0,36^{*}$ \\
\hline$\leq 48$ & 14 & 11,5 & $10,5-16,5$ & & 2,96 & $0,13-100,0$ & \\
\hline$>48$ & 16 & 11,5 & $10,5-13,5$ & & 2,14 & $0,03-100,0$ & \\
\hline Berat badan lahir (gram) & & & & $0,58^{*}$ & & & $0,68^{*}$ \\
\hline$\geq 2500$ & 19 & 11,5 & $10,5-16,5$ & & 4,33 & $0,03-100,0$ & \\
\hline$<2500$ & 11 & 11,5 & $10,5-13,5$ & & 1,03 & $0,13-100,0$ & \\
\hline Hasil kultur darah & & & & $0,81^{*}$ & & & $0,34^{*}$ \\
\hline Positif & 7 & 11,5 & $10,5-16,5$ & & 13,84 & $0,03-100,0$ & \\
\hline Negatif & 23 & 11,5 & $10,5-13.5$ & & 1,44 & $0,13-100,0$ & \\
\hline
\end{tabular}

*Uji Mann-Whitney (nilai kemaknaan $\mathrm{p} \leq 0,05$ )

Tabel 3. Perbedaan skor sepsis modifikasi Tollner dan kadar PCT serum sebelum dengan setelah pemberian antibiotik empiris

\begin{tabular}{|c|c|c|c|c|c|}
\hline \multirow[t]{2}{*}{ Variabel } & \multicolumn{2}{|c|}{$\begin{array}{l}\text { Sebelum pemberian } \\
\text { antibiotik empiris }\end{array}$} & \multicolumn{2}{|c|}{$\begin{array}{l}\text { Setelah pemberian } \\
\text { antibiotik empiris }\end{array}$} & \multirow[t]{2}{*}{$\mathrm{p}$} \\
\hline & Median & Rentang & Median & Rentang & \\
\hline Skor sepsis modifikasi Tollner & 11,5 & $10,5-16,5$ & 5,5 & $0,5-13,5$ & $0,001^{*}$ \\
\hline Kadar PCT serum (ng/mL) & 12,6 & $0,30-100$ & 2,65 & $0,16-37,25$ & $0,017^{*}$ \\
\hline
\end{tabular}

*Uji Wilcoxon (nilai kemaknaan $\mathrm{p}<0,05$ )

Perbedaan skor sepsis modifikasi Tollner dan kadar PCT serum antara sebelum dan setelah mendapat antibiotik empiris tertera pada Tabel 3. Tabel 3 menunjukkan bahwa dengan Uji Wilcoxon, skor sepsis modifikasi Tollner dan kadar PCT serum sebelum dengan setelah mendapat antibiotik empiris pada semua subjek berbeda bermakna.

Korelasi perubahan skor sepsis modifikasi Tollner dan perubahan kadar PCT serum sebelum dengan setelah pemberian antibiotik empiris tertera pada Tabel 4. Tabel 4 menunjukkan bahwa perubahan nilai skor sepsis modifikasi Tollner dan perubahan kadar PCT serum sebelum dengan setelah pemberian antibiotik empiris berkorelasi positif bermakna.

Tabel 4 Korelasi perubahan skor sepsis modifikasi Tollner dan perubahan kadar PCT serum sebelum dengan setelah semberian antibiotik empiris

\begin{tabular}{lcc}
\hline Variabel & Beda PCT & $\mathrm{p}$ \\
\hline Beda skor sepsis modifikasi & 0,353 & $0,028^{*}$ \\
\hline
\end{tabular}

*Uji Rank Spearman (nilai kemaknaan korelasi $\mathrm{p}<0,05$ )

\section{Pembahasan}

Perbedaan didapatkan pada skor sepsis modifikasi Tollner dan kadar PCT sebelum dengan setelah mendapat antibiotik empiris. Pada infeksi bakteri, beberapa faktor yang berhubungan dengan skor sepsis dan peningkatan kadar PCT serum, antara lain jenis kelamin, usia $\leq 48$ jam, berat lahir rendah, dan hasil kultur darah negatif. Beberapa faktor tersebut dalam analisis statistik tidak berbeda sehingga subjek penelitian bersifat homogen. Dengan demikian, perubahan skor sepsis modifikasi Tollner dan kadar PCT serum dapat dianggap berhubungan dengan pengaruh pemberian antibiotik empiris.

Penilaian skor sepsis Tollner terdiri atas parameter klinis dan parameter laboratorium. ${ }^{8}$ Modifikasi skor sepsis Tollner yang dilakukan El Wakeel $\mathrm{dkk},{ }^{13}$ yaitu mengganti analisis gas darah dengan penilaian kadar $C$-reactive protein (CRP) serum. Kondisi klinis yang dinilai saat modifikasi skor sepsis Tollner, antara lain perubahan warna kulit, mikro-sirkulasi (capillary refill memanjang $>2$ detik), hipotonia muskular, bradikardia (denyut jantung $<100$ kali per menit) 
atau takikardia (denyut jantung $>180$ kali per menit), serangan apnea (lebih dari 20 detik), distres pernapasan (takipnea $>60$ kali per menit), pembesaran hati $(>2$ $\mathrm{cm}$ dari bawah arcus costarum), dan munculnya gejala gastrointestinal (residu lambung meningkat, muntah, distensi abdomen, dan diare). Parameter laboratorium dinilai, antara lain CRP kuantitatif serum $(>6 \mathrm{mg} / \mathrm{L})$, jumlah leukosit (leukositosis $>10.000 / \mathrm{mm}^{3}$ atau leukopenia $<4000 / \mathrm{mm}^{3}$ ), pada hitung jenis terdapat peningkatan jumlah neutrofil batang $\geq 20 \%$ atau ditemukan sel muda 'myelo' atau seri eritopoesis, dan trombositopenia (jumlah trombosit $<100.000 /$ $\left.\mathrm{mm}^{3}\right) .{ }^{13}$ Penurunan skor sepsis setelah pemberian antibiotik empiris 48 jam bernilai $<10$ yang berarti menunjukkan perbaikan.

Pada infeksi bakteri, konsentrasi PCT serum meningkat mulai $>0,5 \mathrm{ng} / \mathrm{mL}$ hingga $1-1.000 \mathrm{ng} /$ mL. ${ }^{14,15}$ Kadar PCT serum didapatkan rentang 0,30-100 ng/mL di awal pemeriksaan. Bayi sepsis akan mengalami peningkatan mRNA calcitonin (mRNACT) akibat rangsangan langsung endotoksin maupun eksotoksin; atau secara tidak langsung oleh mediator proinflamasi (Interleukin (IL)-1 $\beta$, tumor necrosis factor (TNF)- $\alpha$, dan IL-6. Peningkatan mRNA-CT akan mengakibatkan pelepasan PCT oleh sel parenkim dalam tubuh ke dalam sirkulasi. ${ }^{16-24}$ Konsentrasi PCT serum akan meningkat dalam waktu 6 jam, mencapai puncak setelah 12 jam, kemudian tetap tinggi hingga 48 jam. ${ }^{15}$ Pemeriksaan kadar PCT pasca pemberian antibiotik empiris selama 48 jam mendapatkan rentang nilai $0,16-37,25 \mathrm{ng} / \mathrm{mL}$ sehingga didapatkan penurunan $44 \%$.

Penelitian terdahulu melaporkan bahwa PCT dapat digunakan untuk pemantauan respons antibiotik apabila ditemukan penurunan $\geq 30 \%$ pasca pemberian antibiotik selama 24 jam. ${ }^{10}$ Stocker $\mathrm{dkk},{ }^{25}$ di Lucerne, Swiss, mengemukakan bahwa PCT serum dapat membatasi penggunaan antibiotik yang tidak perlu pada bayi cukup bulan dan near term dengan sepsis awitan dini apabila kadarnya dalam batas normal pada pemeriksaan dua kali berturut-turut.

Hasil penelitian ini juga menunjukkan korelasi positif antara perubahan skor sepsis modifikasi Tollner dan perubahan kadar PCT serum. Hal tersebut dapat diartikan, kenaikan perubahan skor sepsis antara sebelum dan setelah pemberian antibiotik empiris 48 jam diikuti kenaikan perubahan kadar PCT serum. Korelasi penelitian ini bersifat lemah disebabkan kemungkinan durasi pengamatan yang singkat.
Keterbatasan penelitian ini adalah pemeriksaan skor sepsis modifikasi Tollner dan PCT serum hanya dilakukan dua kali dengan hasil pemeriksaan pada hari ke-3 pasca pemberian antibiotik selama 48 jam ternyata masih relatif tinggi. Hal tersebut kemungkinan disebabkan interval pemeriksaan yang singkat. Pemeriksaan skor sepsis modifikasi Tollner dan kadar PCT serum secara serial diperlukan untuk mengetahui waktu penurunan nilai skor sepsis dan kadar PCT serum ke dalam rentang nilai normal.

\section{Kesimpulan}

Skor sepsis modifikasi Tollner dan kadar PCT serum berhubungan dengan pemberian antibiotik empiris selama 48 jam pada bayi sepsis neonatorum. Kenaikan perubahan skor sepsis modifikasi Tollner akan diikuti oleh kenaikan perubahan kadar PCT serum.

\section{Daftar pustaka}

1. Waseem R, Shah A, Khan M, Qureshi A. Indicators of early outcome in neonatal sepsis. Biomedica 2005;21:117-20.

2. Fraga J, Gracia R, Fernandez L. Neonatal sepsis: epidemiological indicators and relation to birth weight and length of hospitalization time. An Esp Pediatr 1998;48:401-8.

3. Shattuck K, Chonmaitree T. The changing spectrum of neonatal meningitis over a fifteen-year period. Clin Pediatr 1992;31:130-6.

4. Watson R, Carcillo J, Linde-Zwirble W, Clermont G, Lidicker J. The epidemiology of severe sepsis in children in the United States. Am J Respir Care Med 2003;167:695-701.

5. Utomo MT. Neonatal sepsis in low birth weight infants in Dr. Soetomo General Hospital. Indones Trop Infect Dis 2010;1:86-9.

6. Sivanandan S, Soraisham A, Swarnam K. Choice and duration of antimicrobial therapy for neonatal sepsis and meningitis. Int J Ped [serial online] Oct 2011 [diunduh 2 Jan 2013]. [9 screen]. Didapat dari:

http: www.hindawi.com/journals/ijpedi/2011/712150/

7. Leekha S, Terrell CL, Edson RS. General principles of antimicrobial therapy. Mayo Clin Proc 2011;86: 156-67.

8. Töllner U. Early diagnosis of septicemia in the 
Amelia Harsanti dkk: Perbedaan skor sepsis modifikasi Tollner dan PCT serum sebelum dengan setelah pemberian antibiotik

newborn: clinical studies and sepsis score. Eur J Pediatr 1982;138:331-7.

9. Chirico G, Loda C. Laboratory aid to the diagnosis and therapy of infection in the neonate. Ped Reports 2011;3:e1-5.

10. Hatzistilianou M. Diagnostic and prognostic role of procalcitonin in infections. Scie World J 2010;10: 1941-6.

11. Hatzistilianou M, Rekliti A, Athanassiadou F, Catriu D. Procalcitonin as an early marker of bacterial infection in neutropenic febrile children with acute lymphoblastic leukemia. Inflamm Res 2010;59:339-47.

12. Hatzistilianou M, Rekliti A, Athanassiadou F. Serial procalcitonin responsses in infection of children with secondary immunodeficiency. Clin Invest Med 2007;30:75-85.

13. El Wakeel M, El-Kassas G, Fathy G, El Wakkad A, Sebaii $\mathrm{H}, \mathrm{El}$ Zayat S, dkk. Diagnostic and prognostic values of high sensitive C-reactive protein, tumor necrosis factor, and interleukin-1 in neonatal sepsis. Australian J Basic Applied Sciences 2012;6:224-8.

14. Sucilathangam G, Amuthavalli K, Velvizhi G, Ashihabegum M, Jeyamurugan T, Palaniappan N. Early diagnostic markers for neonatal sepsis: comparing procalcitonin (PCT) and C-reactive protein (CRP). J Clin Diag Res 2012;6:627-31.

15. Gendrel D, Bohuon C. Procalcitonin as a marker of bacterial infection. Pediatr Infect Dis 2000;19:679-87.

16. Soreng K, Levy H. Procalcitonin: an emerging biomarker of bacterial sepsis. 2011;33:171-8.

17. Anand D, Das S, Srivastava L. Procalcitonin: a novel sepsis biomarker. Asian J Med Res 2011;1:6-8.

18. LeMoullec J, Jullienne A, Chenais J, Lasmoles F, Guliana J, Milhaud G, dkk. The complete sequence of human preprocalcitonin. FEBS lett 1984;167:93-7.

19. Muller B, White J, Nylen E, Snider R, Becker K, Habener $\mathrm{J}$, dkk. Ubiquitous expression of the calcitonin-I gene in multiple tissues in responsse to sepsis. J Clin Endocrinol Metab 2001;86:396-404.

20. Becker K, Snider R, Nylen E. Procalcitonin in sepsis and systemic inflammation: a harmful biomarker and theurapeutic target. B J Pharmacol 2010;159:253-64.

21. McGee KA, Baumann NA. Procalcitonin: clinical utility in diagnosing sepsis. Clin Lab News [serial online] July 2012 [diunduh 6 Jan 2013]. Didapat dari: URL: http:// www.aacc.org/publications/cln/2009/july/Pages/series0709. aspx\#.

22. Christ-Crain M, Müller B, Philipp S. Procalcitonin and other biomarkers for the assessment of disease severity and guidance of treatment in bacterial infections. Adv Sepsis 2008;6:82-9.

23. Linscheid P, Seboek D, Zulewski H, Keller U, Muller B. Autocrine/paracrine role of inflammation-mediated calcitonin gene-related peptide and adrenomedullin expression in human adipose tissue. Endocrinol 2005;146:2699-708.

24. Christ-Crain M, Muller B. Procalcitonin in bacterial infections-hype,hope, more or less? Swiss Med Wkly 2005; 135:451-60.

25. Stocker M, Hop W, van Rossum A. Neonatal procalcitonin intervention study (NeoPInS): effect of procalcitonin-guided decision making on duration of antibiotic therapy in suspected neonatal earlyonset sepsis: a multicentre randomized superiority and non-inferiority intervention study. BMC Ped. [serial online] 2010 [diunduh 2 Jan 2013]. [8 screen]. Didapat dari: URL: http://www. biomedcentral.com/14712431/10/89 